\title{
ASMENŲ, PATYRUSIŲ GALVOS SMEGENŲ INSULTĄ, KVAPU SUVOKIMO SUTRIKIMAI IR JU巳 KOREKCIJA, TAIKANT ERGOTERAPIJĄ
}

\author{
Emilija Strimaitytė, Viktorija Kaktienė, Daiva Baltaduonienė \\ Kauno kolegijos Medicinos fakultetas
}

Raktažodžiai: galvos smegenų insultas, pažinimo funkcijos, kvapų suvokimo sutrikimai, ergoterapija.

\begin{abstract}
Santrauka
Galvos smegenų insultas (GSI) yra viena pagrindinių priežasčių, sukeliančių sergamumą ir neiggalumą Lietuvoje bei pasaulyje. Tyrimo tikslas buvo ịvertinti asmenų, patyrusių išeminị GSI, kvapų suvokimo sutrikimus ir jų korekcijos efektyvumą, taikant ergoterapiją. Tyrimas buvo atliekamas $2018 \mathrm{~m}$. kovo - gegužès mènesiais Kauno klinikinès ligoninès Fizinès medicinos ir reabilitacijos II skyriuje. Tyrime dalyvavo asmenys, patyrę išeminị GSI. Tyrimo imtis $n$ $=20$. Tyrimui atlikti buvo naudojamas Trumpas protinès būklès testas (TPBT), skirtas ịvertinti asmenų pažinimo funkcijas. Kvapų suvokimo sutrikimams įvertinti buvo naudojamas kvapų suvokimo sutrikimų testas (ang. SOIT - Scandinavian odor identification test), kurį sudaro 16 skirtingų kvapų. Tyrimo rezultatai. Taikant ịprastinę ergoterapiją ir kvapų suvokimą lavinančias užduotis, gerèja pažinimo funkcijos. Tyrimo rezultatai parodè, kad moterys kvapus skiria geriau, nei vyrai, ir prieš tyrimą, ir po jo. Išvados. Visiems asmenims, patyrusiems išemini GSI, po tyrimo pažinimo funkcijos pagerẻjo. Asmenų, kuriems buvo taikoma ergoterapija ir kvapų suvokimą lavinančios užduotys, kvapų suvokimas ir pažinimo funkcijos pagerèjo. Moterys skiria kvapus geriau, nei vyrai.
\end{abstract}

\section{Ivadas}

Išeminį GSI patyrusiems asmenims dažniausiai išlieka judejimo, apsitarnavimo ir pažinimo funkcijų sutrikimų. Išorinio pasaulio suvokimas priklauso nuo jutimo organų - regos, klausos, uoslès, skonio, lytejjimo ir jų gebejjimo perteikti mums informaciją apie objektų savybes. Praradęs sensorinès sistemos funkcionalumą, žmogus nesuvokia ne tik aplinkos, bet ir savo veiksmų bei jų padarinių. Dèl patirto išeminio
GSI praradęs uoslès funkciją, žmogus ne tik nesiorientuoja aplinkoje, bet ir negeba atpažinti gresiančio pavojaus [1]. Ergoterapijos tikslas - padèti asmenims, patyrusiems GSI, būti savarankiškiems kasdienejje, darbinèje ir laisvalaikio veiklose [2]. Pagrindinis ergoterapeuto tikslas - ịvertinti būklę ir siekti, kad asmuo būtų kuo mažiau priklausomas nuo aplinkinių. Ergoterapeutui labai svarbu padèti sugrąžinti prarastas fizines, protines, socialines ir sensorinès integracijos funkcijas [3].

Higienos instituto Sveikatos informacijos centro duomenimis (2018), Lietuvos gyventojų sergamumas kraujotakos sistemos ligomis buvo vienas didžiausių - 30 proc. [4]. Nepalankiausi išeminio GSI padariniai yra šlapimo nelaikymas, pusiausvyros sutrikimas, pažinimo funkcijų sutrikimai, motyvacijos stoka, regèjimo (erdvinio suvokimo) sutrikimai, giliųjų jutimų išnykimas bei ženklūs motorikos sutrikimai. Suprastēja atmintis, dėmesio koncentracija, galimybė planuoti ir atlikti valingus veiksmus, sumažejja tikslingu judesių atlikimo galimybè, asmuo praranda arba iš dalies netenka savarankiškumo [6]. Mokslininkų teigimu, ženklūs pažinimo funkcijų sutrikimai mažina asmens motyvaciją dalyvauti intensyviosios reabilitacijos programoje ūmios ligos fazès metu. Tai labai svarbus laikotarpis asmeniui ir jo sveikimo eigai [7].

Tyrimo tikslas - įvertinti asmenų, patyrusių išeminị galvos smegenų insultą, kvapų suvokimo sutrikimus ir jų korekcijos efektyvumą, taikant ergoterapiją.

\section{Tyrimo medžiaga ir metodai}

Tyrimas buvo atliekamas $2018 \mathrm{~m}$. kovo - gegužès mènesiais Kauno klinikinès ligoninès Fizinès medicinos ir reabilitacijos II skyriuje. Tyrime dalyvavo 20 asmenų, patyrusių išeminį GSI, iš kurių 14 moterų (70 proc.) ir 6 vyrai (30 proc.). Tiriamujų amžius nuo $55 \mathrm{~m}$. iki $87 \mathrm{~m}$. Asmenys buvo atrinkti ir įtraukti ị tyrimą, remiantis šiais atrankos kriterijais: išeminis GSI ịvykęs pirmą kartą, TPBT $\geq 11$ balų. Atmetimo kriterijai: pakartotinis išeminis GSI, TPBT $<11$ balų,

Adresas susirašinèti: Emilija Strimaitytė, el.p. emilestrim@gmail.com 
diagnozuota afazija.

Prieš tyrimą tiriamieji atsitiktinès atrankos būdu buvo suskirstyti į dvi grupes. I tiriamają grupę sudare 10 asmenų, iš kurių 4 vyrai ( 40 proc.) ir 6 moterys ( 60 proc.). II tiriamają grupę sudare 10 asmenų, iš jų 2 vyrai ( 20 proc.) ir 8 moterys ( 80 proc.). Tiriamieji buvo vertinami tyrimo pradžioje ir pabaigoje. Kvapų suvokimo sutrikimams įvertinti buvo naudojamas Kvapų suvokimo sutrikimų testas, kurị sudaro 16 skirtingų kvapų (ang. SOIT - Scandinavian odor identification test) [8]. Pažinimo funkcijoms vertinti naudotas TPBT.

Visiems asmenims, patyrusiems išeminị GSI, buvo lavinamos pažinimo funkcijos pagal individualiai sudarytą ir pritaikytą ergoterapijos programą. Kiekvienam I tiriamosios grupès tiriamajam buvo skirta 15 ergoterapijos užsièmimų, kurių trukmẻ 30 minučių. Užsièmimai vyko 5 kartus per savaitę. Pažinimo funkcijų lavinimui buvo naudojamos įvai-

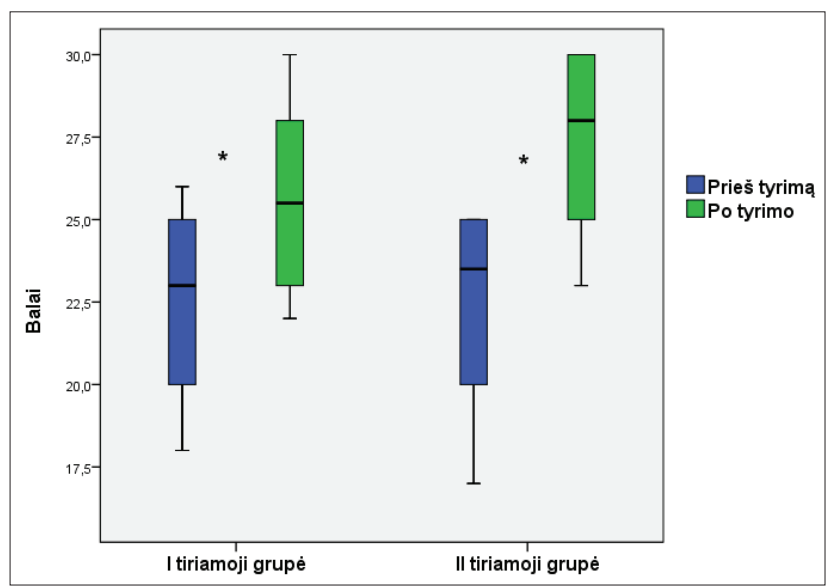

1 pav. Pažinimo funkcijų kaita, vertinant TPBT testu $(p<0,05)$.

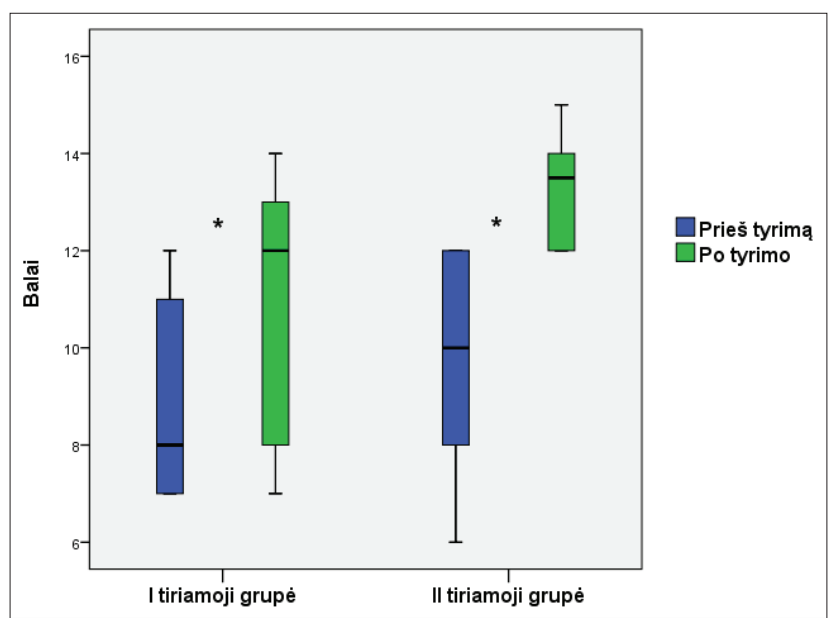

2 pav. Kvapų suvokimo sutrikimų kaita, vertinant $S O I T$ testu $(p<0,05)$. rios ergoterapinès priemonės: skirtingos detalès, raidynai, skaičiai, paveikslèliai. Užduotys buvo atliekamos, ịtraukiant ìvairių formų, spalvų atpažinimą. Nebuvo užduočių, susijusių su kvapų suvokimo lavinimu. Kiekvienam II tiriamosios grupes tiriamajam taip pat buvo skirta 15 ergoterapijos užsiėmimų, kurių trukmė 30 minučių. Užsièmimai vyko 5 kartus per savaitę, itraukiant kvapų suvokimą lavinančias užduotis. Užsièmimų tvarka: 3 kartus per savaitę buvo taikomos pažinimo funkcijas lavinančios užduotys, susijusios su kvapais, o 2 kartus per savaitę buvo lavinamos pažinimo funkcijos, nesusijusios su kvapais, taikant tokias pat priemones, kaip ir I grupès tiriamiesiems.

Pažinimo funkcijų, susijusių su kvapais, lavinimui buvo naudojamos šios užduotys: teste naudojamų kvapų atpažinimas iš paveikslèlių, kvapų buteliukų paveikslèlių ieškojimas pagal pavadinimus, tekstų apie kvapus skaitymas ir atpažinimas, spalvų, susijusių su kvapais, ir kortelių su pavadinimais ir paveikslèliais atminties užduotis.

Statistinè duomenų analizè atlikta naudojantis SPSS Statistics 22.0 programa. Kokybiniai duomenys pateikiami procentine išraiška, kiekybiniai kaip mediana $\left(\mathrm{x}_{\mathrm{me}}\right)$, minimali $\left(\mathrm{x}_{\min }\right)$, maksimali $\left(\mathrm{x}_{\max }\right)$ reikšme ir aritmetinis vidurkis $(\bar{x})$ $-\mathrm{x}_{\mathrm{me}}\left(\mathrm{x}_{\min } ; \mathrm{x}_{\max } ; \bar{x}\right)$. Dviems nepriklausomoms imtims palyginti taikytas neparametrinis Mano Vitney (Mann-Whitney) testas. Dviems priklausomoms imtims palyginti taikytas neparametrinis Vilkoksono (Wilcoxon) testas. Skirtumas laikytas statistiškai reikšmingu, kai $\mathrm{p}<0,05$.

\section{Rezultatai}

Trumpo protinès būklès testo rezultatų kaita I ir II tiriamosiose grupėse. Išanalizavus rezultatus, nustatyta, kad I tiriamosios grupès asmenų TPBT testo suminis balas prieš

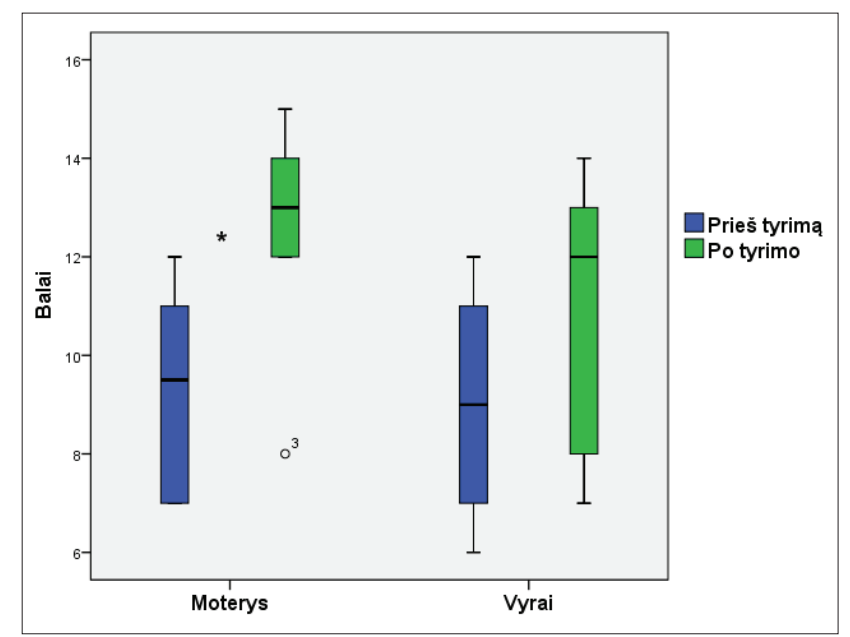

3 pav. Kvapų suvokimo sutrikimų kaita pagal lytị, vertinant SOIT testu, $(p<0,05)$. 
tyrimą buvo $23(18 ; 26 ; 22,30)$ balai, po tyrimo - 25,50 (22; $30 ; 25,80)$ balai. Šios grupès asmenų, kuriems buvo taikoma ịprastinė ergoterapija, pažinimo funkcijos reikšmingai pagerèjo $(Z=-2,623 ; p<0,05)$. II tiriamosios grupès TPBT testo suminis balas prieš tyrimą buvo $23,50(17 ; 25 ; 22,30)$ balai, po tyrimo - $28(23 ; 30 ; 27,40)$ balai. II tiriamosios grupès asmenų, kuriems greta individualios itprastinès ergoterapijos buvo taikomos ir kvapų suvokimą lavinančios užduotys, pažinimo funkcijos statistiškai reikšmingai pagerèjo $(\mathrm{Z}=$ $-2,825 ; \mathrm{p}<0,05)$. Palyginę abiejų grupių TPBT testo rezultatus prieš tyrimą $(U=49,00 ; p=0,939)$ ir po tyrimo $(\mathrm{U}=34,50 ; \mathrm{p}=0,234)$ nenustateme statistiškai reikšmingo skirtumo tarp grupių (1 pav.).

Kvapų suvokimo sutrikimų testo rezultatų kaita I ir II tiriamosiose grupèse. Išanalizavus rezultatus nustatyta, kad I tiriamosios grupès asmenų kvapų suvokimo sutrikimų testo vidutinis suminis balas prieš tyrimą buvo $8(7 ; 12 ; 8,80)$ balai, po tyrimo - $12(7 ; 14 ; 11,30)$ balai. I tiriamosios grupes asmenų, kuriems buvo taikoma ịprastinè ergoterapija, kvapų suvokimas reikšmingai pagerèjo $(Z=-2,546 ; p<0,05)$. II tiriamosios grupés asmenų kvapų suvokimo sutrikimų testo vidutinis suminis balas prieš tyrimą buvo $10(6 ; 12 ; 9,70)$ balų, po tyrimo - 13,50 $(12 ; 15 ; 13,30)$ balų. II tiriamosios grupès asmenų, kuriems greta individualios ịprastinès ergoterapijos buvo taikomos ir kvapų suvokimą lavinančios užduotys, kvapų suvokimas statistiškai reikšmingai pagerèjo $(Z=-2,825 ; p<0,05)$. Lyginant abiejų grupių asmenų kvapu suvokimo sutrikimų testo rezultatus prieš tyrimą, statistiškai reikšmingų skirtumų nenustateme $(U=62,50 ; p=0,337)$; po taikyto poveikio - statistiškai reikšmingo skirtumo taip pat nenustatyta ( $U=73,50 ; p=0,075)$, tačiau stebima tendencija, kad geresnis kvapų suvokimas buvo II tiriamosios grupés asmenų, kuriems ịprastinès ergoterapijos metu buvo taikytos kvapų suvokimą lavinančios užduotys (2 pav.).

Kvapų suvokimo sutrikimų testo rezultatų kaita pagal lytį. Analizuojant asmenų, patyrusių išeminį GSI, kvapų suvokimo sutrikimų kaitą pagal lytị, nustatyta, kad moteru kvapu suvokimo sutrikimu testo suminis ịvertinimo balas prieš tyrimą buvo $9,5(7 ; 12 ; 9,36)$ balo, po tyrimo - 13 $(8 ; 15 ; 12,86)$ balu. Nustatyta, kad moteru kvapu suvokimo testo rezultatas statistiškai reikšmingai po tyrimo padidèjo $(\mathrm{Z}=-3,330 ; \mathrm{p}<0,05)$. Išanalizavus vyrų kvapų suvokimo sutrikimų testo rezultatus, prieš tyrimą šio testo suminis balas buvo $9(6 ; 12 ; 9)$, o po atlikto tyrimo - $12(7 ; 14 ; 11)$ balų, tačiau nenustatytas reikšmingas skirtumas $(Z=-1,89 ; p=$ $0,059)$. Gautų rezultatų analizè parodè, kad moterys skiria kvapus geriau, nei vyrai (3 pav.).

\section{Rezultatų aptarimas}

Asmenų, patyrusių išeminị GSI, pažinimo funkcijų analizès rezultatai parodè, kad esami sutrikimai turi įtakos kvapų suvokimui. Atlikti išsamios palyginamosios analizès nebuvo galimybès, kadangi prieinamoje mokslinejje literatūroje pavyko rasti tik kelis tyrimus, tačiau juose nebuvo analizuojamas kvapų suvokimo sutrikimas asmenims po insulto. Švedų mokslininkai atliko klinikinį tyrimą su žiurkèmis, tyrinejo elgesio ir elektrofiziologinius reiškinius ir ịrodè ryšs tarp uoslès - klausos asociacijų. Tyrèjai padare išvadą, kad sutrikęs gebėjimas nustatyti kvapus yra jautrus esant pažinimo funkcijų nuosmukiui ir galimai neurodegeneracinès demencijos prognozei. Mokslininkų atlikto tyrimo rezultatai parode multisensorinès integracijos svarbą, kuri gali suteikti informacijos apie neuropatologijos poveikị smegenims [8]. Atliktus rezultatus palaiko ir mokslininkai, vykdę tyrimą, kuriame dalyvavo cukriniu diabetu (CD) sergantys asmenys. Mokslininkai tyrinėjo II tipo CD sergančius asmenis bei jų kvapų suvokimo sutrikimus ir padare išvadą, jog uoslès disfunkcija gali būti ankstyvas būsimojo CD rodiklis. Ši mokslininkų grupe atliko pirmaji perspektyvų tyrimą, įrodžiusį tvirtą uoslès disfunkcijos ir atminties sutrikimo ryši sergančiujų CD populiacijoje. Tai rodo, kad sutrikusi uoslè ir kvapų identifikavimas gali atlikti svarbų vaidmeni, prognozuojant būsimus atminties sutrikimus[6]. Japonų mokslininkai, 12os skirtingų kvapų testu ištyrę sergančiujų Parkinsono liga ir su ja susijusiais sutrikimais kvapų suvokimo sutrikimus, padare išvadą, jog sergantieji Parkinsono liga turi ryškių, o sistemine atrofija - lengvų uoslės sutrikimų. Tyrẻjai įrodė, kad kvapų suvokimo sutrikimus būtina diferencijuoti nuo kitų Parkinsono ligos simptomų [7].

\section{Išvados}

1. Visų tiriamujų, patyrusių išemini galvos smegenų insultą, pažinimo funkcijos pagerèjo.

2. Geresnis kvapų suvokimas ir pažinimo funkcijos po tyrimo buvo išemini galvos smegenų insultą patyrusių asmenų, kuriems ergoterapijos metu buvo taikytos kvapu suvokimą lavinančios užduotys.

3. Palyginus kvapų suvokimo sutrikimus tarp lyčių, nustatyta, kad moterys kvapus skiria geriau, nei vyrai. Ju pažinimo funkcijos po ergoterapijos, ịtraukiant kvapų suvokimą lavinančias užduotis, pagerèjo.

\section{Literatūra}

1. Vaitkevičienė G., Vaitkevičius PH. Pojūčiai ir suvokimas: uodimas, skonis, lyta. Vilnius, 2014:335.

2. Wehling E, Naess H, Wollschlaeger D, Hofstad H, Bramerson A, Bende M, et al. Olfactory dysfunction in chronic stroke patients. BMC Neurol 2015;15(1):1-7. http://dx.doi.org/10.1186/ s12883-015-0463-5

https://doi.org/10.1186/s12883-015-0463-5 
3. Shinohara K, Yamada T, Kobayashi N, Forsyth K. The model of human occupation-based intervention for patients with stroke: a randomised trial. Hong Kong J Occup Ther 2012;22(2):60-9. http://dx.doi.org/10.1016/j.hkjot.2012.09.001 https://doi.org/10.1016/j.hkjot.2012.09.001

4. Pugh JD, McCoy K, Williams AM, Bentley B, Monterosso L. Rapid evidence assessment of approaches to community neurological nursing care for people with neurological conditions post-discharge from acute care hospital. Health Soc Care Com 2019;27(1):43-54. https://doi.org/10.1111/hsc. 12576

5. Olofsson JK, Zhou G, East BS, Zelano C, Wilson DA. Odor identification in rats: behavioral and electrophysiological evidence of learned olfactory-auditory associations. Eneuro 2019;6(4):Eneuro.0102-19.2019. https://doi.org/10.1523/ENEURO.0102-19.2019

6. Wolnik B, Orłowska-Kunikowska E, Błaszkowska M, Graff B, Wolf J, Czupryniak L, et al. The phenomenon of HbA1c stability and the risk of hypoglycemia in long-standing type 1 diabetes. Diabetes Res Clin Pract 2019;152:96-102. https://doi.org/10.1016/j.diabres.2019.05.010

7. Watanabe Y, Suzuki K, Miyamoto T, Miyamoto M, Numao A, Fujita H, et al. A card-type odor identification test for japanese patients with Parkinson's disease and related disorders. Intern Med 2017;56(21):2871-8.

https://doi.org/10.2169/internalmedicine.8565-16

8. Pugh JD, McCoy K, Williams AM, Bentley B, Monterosso L. Rapid evidence assessment of approaches to community neurological nursing care for people with neurological conditions post-discharge from acute care hospital. Health Soc Care Com 2019;27(1):43-54.

https://doi.org/10.1111/hsc.12576

\section{ODOUR PERCEPTION DISORDERS AND THEIR CORRECTION WITH OCCUPATIONAL THERAPY IN PATIENTS AFTER STROKE}

\section{E. Strimaitytė, V. Kaktienė, D. Baltaduonienė}

Keywords: stroke, cognitive function, odour perception disorders, occupational therapy.

Summary

Stroke is one of the leading causes of morbidity and disability in Lithuania and worldwide. The aim of the study was to evaluate people after stroke with odour perception disorder and the effectiveness of correction in occupational therapy. Methods of the study. The survey was conducted in 2018 March - May, Kaunas Clinid cal Hospital, 2nd department of Physical Medicine and Rehabilitation. The study involved people after stroke. Test sample $-\mathrm{n}=$ 20. The study used the Mini Mental State Examination (MMSE) to assess individuals" cognitive functions. The Scandinavian Odor Identification Test (SOIT) consisting of 16 different odours was used to assess odour perception. Research results. The results showed that cognitive function improves with conventional occupational therapy and the inclusion of odour awareness tasks. The results of the study also showed that women smell better than men both before and after the study. Conclusions. Cognitive functions of all patients after stroke improved after the study. Individuals" who had occupational therapy with the odour awareness training tasks odour awareness and cognitive functions have improved. Women distinguish smells better than men.

Correspondence to: emilestrim@gmail.com

Gauta 2019-10-21 